\title{
Tingkat pengetahuan dan kecemasan orang tua terkait kesehatan anak dalam menghadapi pandemic covid-19
}

\author{
Dwi Khalisa Putri ${ }^{*}$ \\ ${ }^{1}$ Politeknik 'Aisyiyah Pontianak
}

\section{INFORMASI ARTIKEL:}

\begin{tabular}{l}
\hline Riwayat Artikel: \\
Tanggal diterima: 31 Desember 2020 \\
Tanggal direvisi: 8 Juni 2021 \\
Tanggal dipublikasi: 26 Juli 2021 \\
\hline Kata kunci: Terdiri dari 3-5 kata kunci \\
Tingkat Pengetahuan \\
Kecemasan \\
Kesehatan Anak \\
Covid-19
\end{tabular}

\subsection{6/jrki.v5i1.139}

\begin{abstract}
ABSTRAK
Latar Belakang: WHO memberikan definisi sehat yaitu sempurna baik fisik, mental maupun sosial. Sehingga langkah upaya penanganan Covid-19, idealnya tidak hanya melakukan penanganan pada kesehatan fisik saja melainkan mental dan sosial. Salah satu faktor dari kesehatan mental adalah kecemasan. Penyebab dari kecemasan ini diantaranya karena aspek perilaku, kognitif, mental dan sosial. Aspek kognitif salah satu cirinya susah konsentrasi, terhambat dalam pemikiran, khawatir dan bingung. Hal-hal tersebut dapat terjadi bisa dikarenakan seseorang memiliki pengetahuan yang baik atau bahkan kurang terhadap sesuatu, misalnya tentang pandemic Covid-19 saat ini. Tujuan penelitian: mengetahui Tingkat pengetahuan dan kecemasan orang tua terkait kesehatan anak dalam menghadapi pandemi covid 19. Metode: Desain penelitian ini kuantitatif dengan menggunakan pendekatan cross sectional. Teknik pengambilan Total Sampling dengan jumlah 36 responden. Instrumen penelitian kuantitatif dengan kuesioner. Analisis data kuantitatif menggunakan regresi linier. Hasil: Analisis menunjukan responden yang memiliki pengetahuan baik sebesar $55.6 \%$ dan responden yang memiliki kecemasan dengan level berat yaitu 2,8\%. Simpulan: Tidak ada hubungan antara pengetahuan dan kecemasan orang tua terkait kesehatan anak dalam menghadapi pandemi covid 19.
\end{abstract}

Background: WHO provides a definition of health, namely perfect both physically, mentally and socially. So that, ideally, handling Covid-19 should not only handle physical health, but also mental and social health. One of the factors of mental health is anxiety. The causes of this anxiety include behavioral, cognitive, mental and social aspects. One of the characteristics of the cognitive aspect is difficulty in concentrating, hampered in thinking, worried and confused. These things can happen because someone has good or even less knowledge of something, for example about the current Covid-19 pandemic. Objective: to determine the level of knowledge and anxiety of parents regarding children's health in the face of the COVID-19 pandemic. Method: quantitative research using a cross sectional approach. Total sampling technique with a total of 36 respondents. Quantitative research instrument with a questionnaire. Quantitative data analysis using chi-square. Results of the analysis show that respondents who have good knowledge are $55.6 \%$ and respondents who have anxiety with a severe level are $2.8 \%$. Conclusion: There is no relationship between parental knowledge and anxiety regarding children's health in the Covid 19 pandemic

kasus dan meluasnya penyebaran virus antar wilayah begitu cepat, maka Pemerintah kembali menerbitkan Peraturan Pemerintah nomor 21 tahun 2020 tentang Pembatasan Nasional Berskala Besar dalam Rangka percepatan Penanganan Corona Virus Disease 2019 (COVID-19). Pemerintah juga mempunyai tanggung jawab untuk menjamin setiap warga negara termasuk anak untuk memperoleh pelayanan kesehatan dasar (Kementrian Kesehatan RI, 2020).

Ikatan Dokter Anak Indonesia (IDAI) menyatakan bahwa angka kesakitan dan kematian *orespondensi penulis.

Alamat E-mail: anonim@mail.com 
anak akibat COVID-19 di Indonesia tinggi, dan membuktikan bahwa kelompok usia anak juga rentan terhadap COVID-19 tidak hanya menderita sakit ringan saja. Hal tersebut dibuktikan oleh IDAI berdasarkan hasil data yang ditemukan bahwa Pasien Dalam Pengawasan (PDP) sebanyak 3.324 anak, 129 anak berstatus PDP meninggal, 584 anak terkonfirmasi positif COVID-19, dan 14 anak meninggal akibat COVID-19. Berdasarkan datadata tersebut maka IDAI memberikan anjuran bahwa upaya pemenuhan kebutuhan dasar dan kesehatan anak harus tetap berjalan sesuai jadwal bagi seluruh anak Indonesia serta tetap harus menjaga kesehatan nutrisi lengkap seimbang dan aktivitas fisik sesuai usia (Indonesian Pediatric Society, 2020).

Sehat menurut WHO merupakan suatu keadaan dimana seseorang dalam keadaan sempurna baik fisik, mental maupun sosial. Sehingga langkah upaya penanganan Covid-19 tidak hanya melakukan penanganan pada kesehatan fisik saja melainkan mental dan sosial. Salah satu faktor dari kesehatan mental adalah kecemasan (Muyasaroh, 2020).

Kecemasan merupakan keadaan suasana hati yang ditandai oleh efek negatif dan gejalagejala ketegangan jasmaniah dimana seseorang mengantisipasi kemungkinan datangnya bahaya atau kemalangan di masa yang akan datang dengan perasaan khawatir. Hasil penelitian sebelumnya, menyatakan tentang kecemasan masyarakat menghadapi covid-19 diperoleh hasil 2\% masyarakat Cilacap mengalami kecemasan umum, 12\% kecemasan panik, 7\% kecemasan sosial (Muyasaroh, 2020).

Aspek kognitif salah satu cirinya susah konsentrasi, terhambat dalam pemikiran, khawatir dan bingung. Hal-hal tersebut dapat terjadi bisa dikarenakan seseorang memiliki pengetahuan yang baik atau bahkan kurang terhadap sesuatu, misalnya tentang pandemic Covid-19 saat ini (Muyasaroh, 2020).

Berdasarkan hal tersebut, tujuan dari penelitian ini adalah untuk mengetahui bagaimana Tingkat Pengetahuan Dan Kecemasan Orang Tua Terkait Kesehatan Anak Dalam Menghadapi Pandemic Covid-19

\section{Metode penelitian}

Jenis penelitian ini adalah penelitian kuantitatif dengan pendekatan cross sectional. Sampel dalam penelitian ini adalah ibu yang memiliki anak usia di bawah 5 tahun yang berjumlah 36 orang. Teknik pengambilan sampel yang digunakan adalah purposive sampling.

Jenis data yang digunakan dalam penelitian ini adalah data primer. Sedangkan untuk pengumpulan data hasil pengetahuan dinilai dengan menggunakan kuesioner yang diberikan kepada responden secara online menggunakan google form. Instrumen yang digunakan peneliti adalah Kuesioner pengetahuan tentang Covid-19 (Sesuai dengan panduan dari Depkes) dan kuesioner kecemasan (sesuai dengan Hamilton Anxiety Rating Scale).

\section{Hasil dan Pembahasan \\ Hasil}

Hasil penelitian disajikan dalam Tabel 1 tentang Karakteristik responden berdasarkan Pendidikan dan pekerjaan.

Tabel 1. Karakteristik Responden berdasarkan pendidikan dan pekerjaan

\begin{tabular}{llcc}
\hline No & Kategori & $\mathbf{N}$ & Persentase \\
\hline $\mathbf{1}$ & Pendidikan & & \\
& SD & 0 & 0 \\
& SMP & 0 & 0 \\
& SMA & 4 & 11,11 \\
& D 1/2/3 & 5 & 13,89 \\
& D IV/S1 & 21 & 58,33 \\
& S2 & 6 & 16,67 \\
& S3 & 0 & 0 \\
& Total & 36 & $\mathbf{1 0 0}$ \\
$\mathbf{2}$ & Pekerjaan & & \\
& Bekerja & 30 & 83,33 \\
& Tidak Bekerja & 6 & 16,67 \\
& Total & $\mathbf{3 6}$ & $\mathbf{1 0 0}$ \\
\hline
\end{tabular}

Berdasarkan tabel 1 kolom Pendidikan terlihat bahwa sebagian besar responden memiliki pendidikan DIV/S1 sebesar 21 orang (58,83\%). Sedangkan untuk kolom 2 Pekerjaan sebagian besar responden adalah seorang pekerja yaitu sebesar $83,33 \%$. 


\begin{tabular}{lll} 
& Tabel 2. Pengetahuan tentang covid 19 \\
\hline No & Kategori & Persentase \\
\hline 1 & Baik & $20(55,6 \%)$ \\
2 & Cukup & $16(44,6 \%)$ \\
3 & Kurang & 0 \\
\hline
\end{tabular}

Pada Tabel 2 kolom pengetahuan, terlihat bahwa responden yang memiliki pengetahuan baik sebesar $55.6 \%$.

Tabel 3. Kecemasan tentang covid 19

\begin{tabular}{lll}
\hline No & Kategori & Persentase \\
\hline 1 & Ringan & $31(86,1 \%)$ \\
2 & Sedang & $4(11,1 \%)$ \\
3 & Berat & $1(2,8 \%)$ \\
\hline
\end{tabular}

Pada Tabel 3 tentang kecemasan terhadap Covid-19 terlihat bahwa responden Sebagian besar memiliki kecemasan dengan level ringan sebanyak $86,1 \%$.

Hasil Analisis data menggunakan chi-square yang menyatakan bahwa hipotesis ditolak, sehingga tidak ada hubungan pengetahuan dan kecemasan orang tua terkait Kesehatan anak dalam menghadapi Pandemic Covid-29 ( $p$-value 0,296 lebih besar dari 0,05)

Tabel 4. Hubungan pengetahuan dan kecemasan

\begin{tabular}{lllll}
\hline $\begin{array}{llll}\text { Pengetahuan } \\
\text { Orang Tua }\end{array}$ & \multicolumn{2}{l}{ Kecemasan Orang Tua } & \multirow{2}{*}{ Nilai P } \\
\cline { 2 - 4 } & Ringan & Sedang & Berat & \\
\hline Kurang & 0 & 0 & 0 & $-0,296$ \\
Cukup & $12(75 \%)$ & $3(18,8)$ & $1(6,2)$ & \\
Baik & $19(95)$ & $1(5 \%)$ & 0 & \\
\hline
\end{tabular}

\section{Pembahasan}

Pendidikan kesehatan adalah suatu proses perubahan yang terjadi pada diri seseorang berhubungan dengan tercapainya tujuan kesehatan perorangan dan masyarakat. (Ekajayanti, Purnamayanthi and Larasati, 2019)

Hasil penelitian ini menunjukkan bahwa responden yang memiliki pengetahuan baik sebesar $55.6 \%$ dan responden yang memiliki kecemasan dengan level berat yaitu 2,8\%. Berdasarkan hasil tersebut menunjukkan pengetahuan yang baik akan mengurangi tingkat kecemasan seseorang terhadap Covid-19 ini, karena dapat melakukan pencegahan awal agar resiko tertular akan menjadi kecil.

Penelitian senada dilakukan oleh Suwandim dkk (2020) yang memperoleh hasil bahwa pengetahuan yang baik mengenai Covid-19 belum menjamin tingkat kecemasan yang dialami pasti ringan atau sebaliknya pengetahuan yang kurang akan mengalami kecemasan berat. Penyebab dari kecemasan diantaranya faktor usia, lingkungan, pengetahuan, serta pengalaman dalam menyelesaikan masalah-masalah psikis termasuk kecemasan, dan peran keluarga yang kurang mendukung. (Suwandi \& Malinti, 2020)

Pengetahuan merupakan domain yang sangat penting untuk terbentuknya tindakan seseorang. Karena dari pengalaman dan penelitian ternyata perilaku yang didasari oleh pengetahuan akan lebih langgeng dari pada perilaku yang tidak didasari oleh pengetahuan.(Notoadmodjo, 2010)

Hasil analisis bivariat penelitian ini menunjukkan tidak ada hubungan pengetahuan dan kecemasan orang tua terkait kesehatan anak dalam menghadapi Pandemic Covid-29 ( $p$-value = $0,296, p>0,05)$.

Kecemasan merupakan keadaan suasana hati yang ditandai oleh efek negatif dan gejalagejala ketegangan jasmaniah dimana seseorang mengantisipasi kemungkinan datangnya bahaya atau kemalangan di masa yang akan datang dengan perasaan khawatir. Kecemasan mungkin melibatkan perasaan perilaku dan respon-respon fisiologis. (Feist, J., \& Feist, 2010)

Penelitian sebelumnya yang dilakukan oleh Fitria, dkk (2020), menyatakan bahwa tingkat kecemasan remaja terkait dengan pandemic Covid19 (54\%) berada pada kategori tinggi. Hal ini kemungkinan besar disebabkan karena kurangnya informasi yang diperoleh remaja terkait dengan pandemi covid-19 ini.(Fitria \& Ifdil, 2020)

Berdasarkan hal tersebut maka pengetahuan yang baik akan mengurangi tingkat kecemasan seseorang terhadap Covid-19 ini, karena dapat melakukan pencegahan awal agar resiko tertular akan menjadi kecil. Pada penelitian ini juga dapat terlihat bahwa tingkat pengetahuan responden yang baik mengenai covid-19 dan tingkat kecemasan yang dirasakan juga masuk ke dalam kategori ringan.

Pada hasil penelitian ini juga sebagian besar responden merasakan cemas tentang jika membawa anaknya bertemu orang asing atau berada pada keramaian dan kerumunan orang banyak takut akan tertular virus tersebut, sedangkan untuk pengetahuan tentang covid-19 
ini sangat baik sehingga orang tua mengetahui bagaimana cara mengatasi kecemasan mereka.

Hal tersebut juga didukung oleh penelitian yang dilakukan oleh Rohita (2020) bahwa orang tua telah melakukan perannya dalam mengenalkan Covid-19 ini kepada anak-anaknya dengan menggunakan media TV, smartphone, dan youtube untuk dijadikan contoh dalam tindakan pencegahan dan perlindungan diri dari virus tersebut. (Rohita, 2020)

Penelitian lainnya juga menemukan masyarakat mendapatkan sumber informasi dari media sosial seperti Facebook, instagram, twitter sebesar $41,3 \%$. Hal ini menunjukkan bahwa media sosial menjadi salah satu sumber informasi yang utama bagi masyarakat. (Gumantan, Mahfud and Yuliandra, 2020).

Selain itu, hasil kuesioner mengenai ketakutan yang dirasakan oleh orang tua terkait kesehatan anaknya diperoleh beberapa pernyataan diantaranya orang tua takut terhadap orang sekitar yg tidak sadar bahaya dari Covid 19, takut bertemu orang lain yang bukan keluarga inti, takut bila anak sakit. Banyaknya warga yang meninggal akibat covid-19, Penularan yang cepat terjadi dan komplikasi penyakit yang bisa menjadi berat bahkan kematian. Ketakutan yang dirasakan orang tua ini bisa disebabkan karena pemberitaan di media sosial dan telivisi yang merupakan rujukan utama seseorang dalam mencari informasi secara cepat dan tepat. (Gumantan, Mahfud and Yuliandra, 2020).

Walau demikian tetap ada hal-hal positif yang dapat diambil dari pandemic Covid-19 ini diantaranya menjadi lebih sadar akan pentingnya kebersihan dan kesehatan, bisa memiliki waktu yang banyak untuk berkumpul bersama keluarga serta bisa memantau perkembangan dan kesehatan anak. Berpikiran positif dalam keadaan pandemic covid-19 ini merupakan hal yang utama dalam menjaga sistem imunitas tubuh, karena pikiran cemas dapat memunculkan hormon kortisol dalam tubuh, yang mana hormon ini dapat menyebabkan penurunan sistem imunitas dalam tubuh. (Gumantan, Mahfud and Yuliandra, 2020).

\section{Simpulan}

Hasil penelitian ini menunjukkan bahwa orangtua memiliki tingkat pengetahuan yang baik dengan kecemasan yang ringan. Pengetahuan yang baik akan mengurangi tingkat kecemasan seseorang terhadap Covid-19 ini, karena dapat melakukan pencegahan awal agar resiko tertular akan menjadi kecil. Tidak ada hubungan tingkat pengetahuan dengan kecemasan orang tua terkait dengan Kesehatan anak dalam menghadapi pandemic covid-19.

Penelitian selanjutnya diharapkan dapat mengkombinasikan variabel-variabel lainnya yang dapat dinilai dan berhubungan dengan penanganan Covid-19 ini dengan responden yang lebih luas agar dapat menilai secara keseluruhan

\section{Ucapan terima kasih}

Trimakasih peneliti sampaikan kepada pihak pihak yang telah membantu dalam penyelesaian laporan penelitian ini.

\section{Daftar Pustaka}

Ekajayanti, P., Purnamayanthi, P. and Larasati, N. P. (2019) 'Pengaruh pendidikan Kesehatan Tentang ASI Eksklusif terhdap Peningkatan Pengetahuan Ibu dalam Pemberian ASI Eksklusif di PMB Hj. Sulini Denpasar', Jurnal Medika Usada, 2(1), pp. 1-7.

Feist, J., \& Feist, G. J. (2010) Teori Kepribadian. Jakarta: Salemba Humanika.

Fitria, L. and Ifdil, I. (2020) 'Kecemasan remaja pada masa pandemi Covid -19', Jurnal EDUCATIO: Jurnal Pendidikan Indonesia, 6(1), p. 1. doi: 10.29210/120202592.

Gumantan, A., Mahfud, I. and Yuliandra, R. (2020) 'Pemberlakuan New Normal Dan Pengetahuan', Sport Scienc and Education Journal, 1(2), pp. 18-27.

Indonesian Pediatric Society (2020) 'Anjuran Ikatan Dokter Anak Indonesia Menjelang Akhir Masa Tanggap Darurat COVID-19', Indonesian Pediatric Association, (5), pp. 45. 
Kementrian Kesehatan RI (2020) 'Panduan Pelayanan Kesehatan Balita Pada Masa Tanggap Darurat COVID-19', Kementrian Kesehatan RI, pp. 1-30. Available at: https://covid19.go.id/p/protokol/panduanpelayanan-kesehatan-balita-pada-masapandemi-covid-19.

Muyasaroh, H. (2020) 'Kajian Jenis Kecemasan Masyarakat Cilacap dalam menghadapi Pandemi Covid 19', LP2M UNUGHA Cilacap, p. 3. Available at: http://repository.unugha.ac.id/id/eprint/85 8.

Notoadmodjo, S. (2010) Metodologi Penelitian Kesehatan. jakarta: PT Rineka Cipta.
Rohita, R. (2020) 'Pengenalan Covid-19 pada Anak Usia Prasekolah: Analisis pada Pelaksanaan Peran Orangtua di Rumah', Jurnal Obsesi : Jurnal Pendidikan Anak Usia Dini, 5(1), p. 315. doi: 10.31004/obsesi.v5i1.528.

Suwandi, G. R. and Malinti, E. (2020) 'Hubungan Tingkat Pengetahuan Dengan Tingkat Kecemasan Terhadap Covid-19 Pada Remaja Di SMA Advent Balikpapan', Malahayati Nursing Journal, 2(4), pp. 677-685. doi: 10.33024/manuju.v2i4.2991. 